\title{
THE BRITISH SCORCHED EARTH AND CONCENTRATION CAMP POLICIES IN THE POTCHEFSTROOM REGION, 1899-1902 ${ }^{1}$
}

\author{
Prof GN van den Bergh \\ Research Associate, North-West University
}

\begin{abstract}
The continued military resistance of the Republics after the occupation of Bloemfontein and Pretoria and exaggerated by the advent of guerrilla tactics frustrated the British High Command. In the case of the Potchefstroom region, British aggravation came to focus on the successful resurgence of the Potchefstroom Commando, under Gen. Petrus Liebenberg, swelled by surrendered burghers from the Gatsrand again taking up arms. A succession of proclamations of increasing severity were directed at civilians for lending support to commandos had no effect on either the growth or success of Liebenberg's commando. His basis for operations was the Gatsrand from where he disrupted British supply communications. He was involved in British evacuations of the town in July and August 1900 and in assisting De Wet in escaping British pursuit in August 1900. British policy came to revolve around denying Liebenberg use of the abundant food supplies in the Gatsrand by applying a scorched earth policy there and in the adjacent Mooi River basin. This occurred in conjuncture with the brief second and permanent third occupation of Potchefstroom. The subsequent establishment of garrisons there gave rise to the systematic destruction of the Gatsrand agricultural infrastructure. To deny further use of the region by commandos it was depopulated. In consequence, the first and largest concentration camp in the Transvaal was established in Potchefstroom. The policies succeeded in dispelling Liebenberg from the region.
\end{abstract}

\section{Introduction}

Two of the most controversial aspects of the Anglo Boer War are the closely related British scorched earth and concentration camp policies. Consequently, both

Scientia Militaria, South African Journal of Military Studies, Vol 40, Nr 2, 2012, pp. 72-88 doi: $10.5787 / 40-2-997$ aspects have been thoroughly researched. ${ }^{2}$ This article examines the role of the Gatsrand and Mooi River agricultural regions immediately north of Potchefstroom in the formative phase of the scorched earth policy, emanating from 
which was the opening of a concentration camp in Potchefstroom - arguably the first in the Transvaal. These events may have served as role model for comparable scorched earth and concentration camp policies elsewhere in territories occupied by the British.

A brief summary of events and policies preceding the introduction of the scorched earth and concentration camp policies is given in this article. When Frederick Lord Roberts assumed command of the British forces in January 1900, he foresaw a speedy termination of hostilities. The success with which he conducted the British offensive and which led to the occupation of Bloemfontein in March of that year, bolstered that expectation. By then the lingering military concern was the disruption of communications behind the front, particularly those effecting crucial railway communications with the Cape harbours.

Roberts' early proclamations directed at the enemy fall into two groups, both reflecting his undiminished optimism. One group was aimed at burghers still on commando, and the second at civilians and surrendered burghers. Burghers still active were given the assurance that if they lay down their arms and undertook an oath of neutrality they would be allowed to return to their farms without impediment. By the time Roberts had occupied Johannesburg in May 1900, his attitude had undergone a radical change. ${ }^{3}$ Further disenchantment followed when the republican governments did not sue for peace after the capture of their capitals and the industrial Witwatersrand. The patience which had shaped his accommodating attitude during the preceding months now gave way to a sense of urgency bordering on desperation, ${ }^{4}$ exasperated by the advent of the guerrilla phase of the war.

Additional to this was the large number of burghers who had sworn neutrality and then resumed the armed struggle. It was realised that the only motive for swearing neutrality was that it was a requirement for the burghers to return to their farms. ${ }^{5}$ The British Forces henceforth impounded their animals and harvests. By September, unable to contain the guerrilla war, Roberts ordered that all males of military age encountered in the vicinity of active commandos were, without further ado, to be treated as prisoners of war. ${ }^{6}$

Events in the Potchefstroom district were in no small measure cause to Roberts' discomfort. The cause of this was the astonishing appearance of an active Boer commando in that district in July 1900 at a time when the last hostilities were apparently being concluded in the south-eastern corner of the Transvaal. 


\section{Military considerations for the scorched earth policy}

In considering the place of Potchefstroom in the establishment of the scorched earth and concentration camp policies there it is necessary to take note of the military position in the western Transvaal by the middle of 1900 .

The original objective of the British offensive, once the Boer incursion into the Cape Colony had been repulsed, was to move northwards parallel to the Kimberley-Rhodesia railway line along the western border of the Free State and invade the Transvaal from its south-western edge towards Johannesburg and Pretoria. At the time of the Battle of Magersfontein in February 1900, this strategy was changed. Roberts then decided to move into the Free State first and occupy Bloemfontein before invading the Transvaal. The result was that invasion of southwestern Transvaal was postponed. Only after the occupation of Pretoria in May were small garrisons placed in a number of towns in the western Transvaal. Ventersdorp was occupied on 11 June 1900 and Potchefstroom and Klerksdorp two days later. The occupation of lesser towns farther westward was left for a later date.

General Geoffry Barton, with headquarters in Krugersdorp, commanded the British forces in that region. This placed him in nominal control of the section of the south-western railway line running between Krugersdorp and Klerksdorp, and passing along the western edge of the Gatsrand. Bank (present-day Carletonville), Welverdiend and Frederikstad were stations along that part of the line north of Potchefstroom. What was expected to be routine actions were to be rudely disrupted by the introduction of guerrilla war within a month of the occupation of Potchefstroom

\section{Reactivation of the Potchefstroom Commando}

When in June the republican councils of war determined to switch to guerrilla tactics, the first step was to remobilise the commandos and to escalate the conflict to a regional level. The effort in the Western Transvaal was to be commanded by General Koos de la Rey. His first steps were to replace incompetent officers by ones in whom he placed greater trust. ${ }^{7}$ For the Potchefstroom district, Combat-Gen. Petrus Liebenberg was placed in command. ${ }^{8}$ This was remarkable as De la Rey entertained doubts about both the merits of Liebenberg and his ability to reactivate the disgraced Potchefstroom Commando. His misgivings about the Commando were based on its poor showing during the conventional phase of the war. Of the 4000 burghers who had surrendered at Paardeberg in December 1899 
the vast majority - 13 officers and some 1900 burghers - were members of the Potchefstroom Commando. ${ }^{9}$ Low morale had characterised its remnants after Paardeberg, which led to a measure of desertion. ${ }^{10}$

De la Rey hoped to overcome his misgiving by attaching State Attorney Jan Smuts to Liebenberg to act as his legal advisor and, more specifically, to compel those burghers who had abandoned the struggle to rejoin the Commando. The rapid growth in numbers of Liebenberg's force is testimony of Smuts' success. The outcome was, in the words of Smuts, that Liebenberg was destined to create "a pandemonium for his bewildered enemies". ${ }^{11}$

When Liebenberg first made his appearance in the Potchefstroom district in July 1900, he commanded some 300 burghers. ${ }^{12}$ De la Rey's victory at Silkaatsnek ${ }^{13}$ on 11 July and Liebenberg's own occupation of Ventersdorp and Klerksdorp two weeks later resulted in a spontaneous flow of new recruits. ${ }^{14}$ These efforts brought some 200 more men to arms. In the space of two months, the vast majority of Gatsrand burghers, either willingly or under duress, had returned to Liebenberg's banner.

By September, senior British officials acknowledged that efforts to pacify remote territories where commandos were active, were difficult. ${ }^{15}$ By October, the British high command was convinced that every able-bodied male in the Gatsrand had rejoined the struggle. ${ }^{16}$ By that time, the Potchefstroom Commando numbered around 700, while only one burgher had surrendered to the British voluntarily during September. ${ }^{17}$

De la Rey's military successes in the Magaliesberg led to Roberts withdrawing all the garrisons he had placed in smaller centres west and north of Pretoria and Johannesburg. Potchefstroom was a different matter. Maintaining a hold on it had become vital for various reasons. Losing Ventersdorp and Klerksdorp had emphasised the importance of holding Potchefstroom. Control of the town also carried a moral obligation as, next to Johannesburg and Pretoria, it had the most sizable British population in the Transvaal. Finally, whatever expectations there were of subjecting Western Transvaal, now a distant objective, control of the railway line between Krugersdorp and Potchefstroom had to be secured. Liebenberg was to make this a very difficult task. 


\section{Focus on the Gatsrand}

For his base of operations, Liebenberg chose the extensive, hilly, fertile and sheltered Gatsrand region between Potchefstroom and the present Carletonville. The area not only offered security and provisions but also constituted an immediate threat to British control of the adjacent and crucial railway, road and telegraph communications. His presence was effective enough to cause Maj. Alan Gough, who commanded the small garrison in Potchefstroom, to complain that he was in a state of siege, could not risk sending patrols outside of the town's limits and was obliged to use volunteers among the loyalists to man the trenches at the entrances to the town. ${ }^{18}$

While the experience of Gough can be regarded as a local discomfort, a series of more serious military events were to bring Liebenberg and the Gatsrand into sharper focus at Roberts' headquarters. Potchefstroom was evacuated twice within three months of its first occupation. The first of these was on 8 August 1900, when the small Potchefstroom garrison was required to accompany Gen. Paul Methuen in the first drive on Gen. De Wet. ${ }^{19}$ During the drive, the extent of Liebenberg's worrying disruption of the British lines of communication along the Gatsrand obliged Methuen to detach 1500 troops under Gen. Horace Smith-Dorrien to guard the rail line past the Gatsrand. ${ }^{20}$ Smith-Dorrien described Gatsrand as a "hotbed of Boers" and considered himself so tied up with this task that he was not able to make an active contribution to the drive on De Wet. ${ }^{21}$ The validity of SmithDorrien's distress was demonstrated when, after having eluded Methuen at the Battle of Tygerfontein on 7 August, De Wet slipped across the Gatsrand, guarded at that time by no fewer than four British generals, and effected another of his many escapes. To rub salt into the wounds, Liebenberg not only assisted De Wet safely through his Gatsrand lair, but also joined him with a part of his commando on his journey further northward.

Crucially, Gough's departure allowed elements of Liebenberg's burghers to occupy Potchefstroom, further shrinking British control over Western Transvaal. Analysing the reasons for the failure of the De Wet drive and the loss of Potchefstroom, the British high command came to focus on Liebenberg and the Gatsrand. It was then believed that De Wet had been provided by Liebenberg with food supplies from the Gatsrand horn of plenty over an extended period. ${ }^{22}$

The effect of the failed drive on local policy was that a stern attitude toward civilians in the region was indicated. In effect, the founding of the scorched earth 
policy in the Gatsrand region traces its origins to the De Wet drive. By that time, farm destruction and seizure of animals had been in practice, initially on a selective basis and on a small scale. ${ }^{23}$ By June, such actions were guided by proclamations and instructions. ${ }^{24}$ As elsewhere, the earliest incidents revolved around railway disruption behind the frontlines, initially in the Free State, but by July there had been seven incidents in the Transvaal of which three on the section between Bank and Frederikstad, one of which caused a derailment. ${ }^{25}$ During August, while the De Wet's drive was in progress, the line was blown up at least four times in that vicinity. In one of these incidents, 14 of Smith-Dorrien's troops were killed. ${ }^{26}$ These incidents contributed to Methuen having detached a large section of his force to guard some $35 \mathrm{~km}$ of the line while he pursued De Wet. Two railway bridges north of Potchefstroom were also severely damaged. ${ }^{27}$

At first farmsteads in the vicinity of such occurrences, and where the occupants were suspected of having part therein, were burnt down. Later destruction also befell the property of families whose menfolk were still on commando or who were suspected of being witnesses to such acts but not reporting them. ${ }^{28}$ After July, no investigation was required prior to destroying buildings. Starting in August, all animals within $16 \mathrm{~km}$ of the occurrence were confiscated. ${ }^{29}$ By then, British commanders had come to the realisation that farms, like those in the fertile Gatsrand, served as supply depots for commandos active in the region. Such farms were to be razed to the ground. ${ }^{30}$ Incomplete statistics indicate that, whereas twelve buildings were destroyed in Transvaal in August, the number for September had jumped to 189 of which a mere seven could be identified as in the Potchefstroom district. ${ }^{31}$ By the end of that month, Roberts supported the view that "it is absolutely essential to force all the people south of the Magaliesberg to submit and it is now clear that this can only be done by severe measures. You (commanding officers) must please have no mercy, and what you cannot bring away, you must destroy." 32 This policy was to include Barton's command.

\section{The second occupation of Potchefstroom - establishing the policy}

While urgent strategic considerations demanded a reoccupation of Potchefstroom, the progress of the De Wet chase past the town exposed a crucial prerequisite if control of the town was to be ensured. Securing Potchefstroom required control of the Gatsrand and that in turn, the expulsion of Liebenberg.

The realisation of all this was entrusted to Gen. Arthur Hart, the necessity of effectively pacifying the Gatsrand being included in his operational brief. Roberts' 
operational order required Hart to "stamp out the resistance of the remaining scattered forces of the enemy by hunting them" 33 and to facilitate that task by "depriving them of their supplies of food and transport". 34 This was to be achieved by applying existing proclamations 'severely'. The newly conceived scorched earth policy was to be visited on the Gatsrand and Mooi River basin. At this stage, two checks were imposed. Burning was to be limited to "certain farms", and, while all animals were to be carried off, receipts were to be issued where there was proven "loyalty or, where no evil practice has been proven". ${ }^{35}$ Hart skilfully convinced his troops of the need for the added task. One of them noted in his diary:

I felt very sorry for the poor people whose homes were being burnt; but it is the only thing to be done now to end the war, which will not continue more than two or three months in my opinion. ${ }^{36}$

En route to Potchefstroom, Hart executed the first of his tasks by zigzagging across the Gatsrand and Mooi River with the purpose of "clearing this hostile region of its abundant supplies". ${ }^{37}$ On the first day of operations, he seized 600 head of cattle, 1200 sheep and goats and 13 wagonloads of fodder ${ }^{38}$ and reported, "the Intelligence Department well described this locality as a depot of supply for Boers still under arms". 39 'Foraging' required so much effort that he was obliged to ask for reinforcements and parcel out his force. This allowed Liebenberg, with whom he was continuously skirmishing, to inflict casualties incommensurate with the size of Hart's force. ${ }^{40}$ While these factors delayed his march to Potchefstroom, ${ }^{41}$ it allowed him to gather in another 1340 sheep and cattle and 400 bags of maize. ${ }^{42}$ On 5 September, he was re-supplied at Welverdiend and then moved north-westwards along the Mooi River to burn down the settlement at Klerkskraal. ${ }^{43}$

Eventually, on 9 September, the occupation of Potchefstroom was achieved. ${ }^{44}$ From there patrols were sent out to continue the devastation of the district. ${ }^{45}$ Liebenberg, who skilfully avoided a pitched battle with Hart, was enough of a pestilence to force Hart to emulate Smith-Dorrien by complaining that he could not both occupy the town efficiently and carry out his plundering of the region. He resolved the problem by effectively evacuating Potchefstroom within a week of occupying it to concentrate his efforts on farm destruction. In order to pacify the remaining loyalists in the town he left a nominal garrison. ${ }^{46}$ Dissatisfied with Hart's progress, Roberts, after consulting Barton, recalled him on 22 September. ${ }^{47} \mathrm{He}$ returned to Krugersdorp with 6000 animals, 1599 bags of grain and an assortment of 378 vehicles. What he could not carry off was destroyed. ${ }^{48}$ In that regard, Hart had set an example for future operations in the area. 
He returned also with 96 prisoners of which some 70 were townspeople who had been pointed out by British agents and loyalists as republican agitators. Hart described them as "prisoners of war, those who had broken their oaths and those who are desirable to remove". The latter included a number of women and children. ${ }^{49}$ Few of the group had been militarily active.

Despite having carried out his burning instructions diligently, Hart's inability to expel Liebenberg from the Gatsrand and his failure to secure a hold on Potchefstroom set him in disfavour with Barton and Roberts and caused his recall. Even his actions in the Gatsrand were judged as indicative of his being "too soft hearted", which, it was argued, "in this ... thoroughly disturbed district ... is not deserved", rather "calling for severe penalties and reprisals". ${ }^{50}$ It is remarkable that the criticism lavished on Hart revolved around Liebenberg and the Gatsranders and made no reference to his evacuation of Potchefstroom.

\section{The third occupation - applying the policy}

By the time of Hart's return, plans for a new onslaught on Liebenberg, the Gatsrand and Potchefstroom had already been set in motion. Outwardly, the aims were the same as in Hart's case, but in effect, the emphasis had shifted to Liebenberg's expulsion. The occupation of Potchefstroom was to be a consequence of the operation rather than its main aim. It was emphasised that firm occupation of the town could not be contemplated without the Gatsrand first being pacified and secured, as a consequence, by placing a strong garrison in Potchefstroom. ${ }^{51}$

This time Barton himself undertook the task. Again, he moved along the railway and was regularly supplied and reinforced along the way. Equally predictable was his regular skirmishes with the persistent Liebenberg.

The "badly broken bridge" 52 at Frederikstad was identified as a crucial factor in securing supplies for the final move to Potchefstroom. It obliged Barton to stop there until sappers could assess the damage and effect repairs. Unless that was done, the occupation of Potchefstroom would require new supplies to be carried in wagons from Frederikstad to Potchefstroom over a distance of $30 \mathrm{~km}$. The delay at the bridge took more time than had been anticipated, compelling Barton to deploy his force in extended defensive positions. ${ }^{53}$ While Liebenberg, who had drawn a thin semi-circle to the east around Barton, could prevent him from sending patrols to 
ravish farms eastwards into the Gatsrand, he could not stop him from excursions along the Mooi River.

The situation presented a strategic reversal. It was now the British and not the Boers who were on the defensive. In Barton's long delay at the bridge Liebenberg perceived an unprecedented opportunity of inflicting a defeat on Barton. To enhance the chances of success he appealed to Gen. De Wet, then in the Northern Free State, for assistance. Liebenberg's enterprise was to be disastrous. The Battle of Frederikstad, which lasted from 20 to 25 October 1900, resulted in a serious defeat for the Boer generals.

All the aims of Barton's operation were accomplished in one blow. His task of clearing the Gatsrand of a significant Boer presence was not his own doing. It had been accomplished for him by Liebenberg exchanging his guerrilla tactics of hit and run, for a rash offensive action. Liebenberg was compelled to forsake the Gatsrand with the bulk of his commando, and the third and final British occupation of Potchefstroom was assured. ${ }^{54}$ The departure of Liebenberg removed whatever check there was on applying the scorched earth policy around Potchefstroom. Hard times awaited the farms in the Gatsrand and Mooi River valley.

The expulsion of Liebenberg and the undisputed control of Potchefstroom resulted in the implementation of the concentration camp policy. Thus far vague and undefined, it was now evoked as the permanent solution for the unruly Gatsrand and as the logical outcome of the scorched earth policy.

\section{Civilian administration}

The scorched earth policy was a military responsibility. The origins of the Potchefstroom camp can be traced to the proposals of two military officers, emanating from their responsibilities as civilian administrators.

While overall command rested with Lord Roberts, separate military governors to control civilian affairs were appointed for Pretoria and Johannesburg. Under their control, commissioners were appointed in various districts. Military control of the Krugersdorp region included Potchefstroom and rested, as has been seen, with Gen. Barton. On the other hand, by August 1900, civilian control of the whole region rested in the hands of district commissioner Lt-Col. AHM Edwards. $\mathrm{He}$ had been posted in Potchefstroom but as commissioner was moved to Krugersdorp and was succeeded by Maj. Harold Sykes in Potchefstroom. ${ }^{55}$ 
Both commissioners were competent but controversial. In Potchefstroom, their concern was limited to the needs, particularly regarding foodstuffs, of the large number of British residents. For the republican-minded Boers in and around the town, they had nothing but revulsion. In accordance with established policy, Edwards threatened the expulsion of families whose menfolk were still on commando. ${ }^{56}$ In retrospect, Edwards' appeal to Liebenberg to surrender for the sake of averting famine in the town ${ }^{57}$ sounds naive, but must be seen in the context of the British expectations at the end of July that the capitulation of all the Boer forces was imminent. Concern over continued hostilities in the region, by then focusing on the Gatsrand, was therefore shared by Edwards. General instructions to civil authorities to prevent precious food supplies falling into the hands of commandos ${ }^{58}$ were hardly sufficient measures to ensure food for starving loyal civilians. While agreeing with military commanders that Liebenberg was the target and the Gatsrand the main area of operations, his interest was for his charges and not the ultimate establishment of British control over western Transvaal. So great was Edwards' concern for the British civilians in Potchefstroom that he accompanied those among them who chose to leave the town, in fear of reprisals by republican-minded inhabitants, when Methuen left in early August to pursue De Wet. Edwards' justification for that was the inhabitants' fear of starvation. ${ }^{59}$

Edwards' action was repeated by his successor, Sykes. Hart also evacuated Potchefstroom a month later. He too felt obliged to accompany a second group of Britons who left with the British garrison. Like Edwards in August, Hart justified evacuating the civilians because they complained of "fear and famine". 60 The continued domination of Liebenberg which all but cut off food supplies to the town, weighed heavily against the plenitude which the commando enjoyed within a stone's throw of Potchefstroom, and turned Edwards and Sykes into scorched earth champions.

Once the Battle of Frederikstad had both removed effective military resistance in the Gatsrand and secured British control of the town, Sykes, having returned to Potchefstroom, immediately set about compiling an inventory of the agricultural infra-structure of the Gatsrand and Mooi River, which was to serve as a guide for the continued implementation of the scorched earth policy, now to be put into full and uninhibited operation.

By November, application of the policy in Potchefstroom had been systematically introduced over a period of five months. During that time, it 
demonstrated all the elements, which led to the formulation of the policy - remobilisation, rail dislocation, harbouring and supplying of commandos, successful guerrilla tactics and, for the British, supply disruptions. It also contained a new element. Selected farms were no longer targeted, but rather an entire region of some $2400 \mathrm{sq} \mathrm{km}$ and containing some 75 farms at the time of the original Voortrekker settlement, many of which were now subdivided. ${ }^{61}$ It was, in its final form, applied without distinction of persons - Boer and British sympathisers, republicans and foreign nationals - all of the farming community was to be targeted.

In the course of the first two weeks of December, the new Potchefstroom garrison destroyed 3600 metric tons of oats, maize and hay on the Mooi River farms north of the town alone. Along the $20 \mathrm{~km}$ between Potchefstroom and Frederikstad no fewer than 49 mills for domestic use were disabled. ${ }^{62}$

A month earlier, Gen. Charles Douglas en route to reoccupy Ventersdorp, managed to round up 10400 head of cattle, sheep and goats and 430 horses. ${ }^{63}$ These figures do not include lesser hauls, or of animals such as pigs and poultry, which were effected daily by patrols. Already in November 1900, Roberts had informed the British government that crops in the Transvaal and Free State were ready to be harvested. He expressed the opinion that through the implementation of the scorched earth policy "the country will indeed be in a terrible condition ... all we cannot make use of are being destroyed". ${ }^{4}$

\section{The concentration camp}

Camps of some form or another for burghers and their families who had accepted British rule and had experienced some form of uprooting had been in operation since approximately September $1900 .{ }^{65}$ These camps were the only authentic refugee camps for whites. By November, this policy was to blossom into an inflexible concentration camp policy, finding one of its earliest applications in Potchefstroom.

The ravaging of the fertile area north of Potchefstroom was accompanied by the opening of a concentration camp within weeks after the third British occupation on 26 October. Already on 1 August, soon after Methuen's arrival in Potchefstroom to participate in the De Wet drive, Edwards and Sykes wrote separate letters, one to Roberts' advisor for civilian affairs, and the other to the military secretary, proposing the establishment of a refugee camp in Potchefstroom to give protection 
to surrendered farmers who were peacefully inclined, but who were being forced to rejoin the commando. ${ }^{66}$

The proposals were made separately. Edwards wrote his letter from Krugersdorp on 1 August, immediately prior to following Methuen to Potchefstroom. Sykes was already there when Methuen arrived on $30 \mathrm{July}^{67}$ It therefore seems likely that Edwards influenced his subordinate Sykes to write a separate letter in the same vein, which he did on 4 August. Roberts rejected the proposals, possibly feeling, that the prevailing favourable military situation did not justify such a step. ${ }^{68}$

At the time of the third occupation, the attitude of the commissioners had changed radically. By then both were aware of the success Smuts had achieved in remobilising the Potchefstroom Commando. In addition, there was the insecure British control over Potchefstroom and its environs, considerations, which at first made the establishment of such a camp impractical and was to change its character when secure control of the region had been established two months later.

Sykes, who had left Potchefstroom when Hart was recalled to Krugersdorp, returned to Potchefstroom, as it were, in the baggage train of Barton, who referred to him as the "District Police Officer". ${ }^{69}$ By then, Sykes in Krugersdorp had nursed his aversion toward the republicans who had been his bane in the region. On the eve of his return, he expressed the opinion to headquarters in Pretoria that "the best way to deal with the inhabitants (of the region) is to bring in the women and children and destroy all sources of supply and so starve them (the burghers) into subjection". 70

This time the implementation of Sykes' views was approved by Roberts who gave direct orders to open, what Sykes claimed to be the first concentration camp in Transvaal, ${ }^{71}$ in Potchefstroom within weeks after the final occupation of the town. The camp did indeed, in line with Sykes' original proposal, house some refugees, ${ }^{72}$ many of whom came to the town fearing molestation by blacks after Liebenberg's vigilance had ended, ${ }^{73}$ but the main purpose of what had now undergone a metamorphosis from a refugee camp into a concentration camp, was to house the population of the Gatsrand. The first inmates were farmer families rounded up by the new Potchefstroom garrison, but the new policy of bringing into town those who were to be termed "undesirables", was a reversal of the previous policy of deporting them to be cared for by the commandos and which the commissioners described as a failure. 
By mid-November there were 592 of these adults in the town and camp and 911 children. Five months later the figure was $5724,{ }^{74}$ which made it the largest camp in Transvaal. At the end of May 1901, the figure stood at $6149,{ }^{75}$ some $25 \%$ of the total number of concentration camps residents countrywide. ${ }^{76}$ By September, it reached its peak of 7 542. Edwards and Sykes, the architects of the Potchefstroom concentration camp, had triumphed and set the depopulation of the Gatsrand in motion.

\section{Conclusion}

Scorched earth and concentration camps did not feature in the original British planning of the war. Initial strategic planning revolved around confronting the republican field armies in pitched battles along a defined front, defeating them and concluding the war with the occupation of their capitals. The war was to be brief and decisive. Consequently, little attention was given to wartime civilian administration in occupied regions.

The advent of guerrilla warfare dramatically exposed the shortcomings of both British military expectations and the pacification of the civilian population. Frustration led to a radical change in British policy. Events in the Gatsrand region between July and November 1900 serve to illustrate the extent to which attitudes toward the civilian population escalated firstly into the application of the scorched earth policy and inevitably into the establishment of a concentration camp there.

\section{Endnotes}

${ }^{1}$ This article is parallel to Van den Bergh, GN. The three British occupations of Potchefstroom during the Anglo-Boer War 1899-1902. Scientia Militaria 37/1. 2009. 95 .

${ }^{2}$ See for example, Buys, MH. "Militêre regering in Transvaal 1900-1902". DPhil dissertation. University of Pretoria, 1972; Hattingh, JJ. "Die Irene konsentrasiekamp". Archives Yearbook for South-African History. Part 1. Pretoria: Government Printer, 1967; Martin, AC. The Concentration Camps 1899-1902: Facts, figures and fables. Cape Town: Timmins, 1957; Otto JC. Die konsentrasiekampe. Cape Town: Nasionale Boekhandel, 1954; Spies, SB. Methods of barbarism? Cape Town: Human \& Rousseau, 1977; Pretorius, F (ed). Verskroeide aarde. Cape Town: Human \& Rousseau, 2001. 
${ }^{2}$ The remarkable change in Roberts's attitude is reflected in his proclamations regarding civilians that were published in British Blue Book Cd 426, 1-20.

${ }^{4}$ See Wessels, A. "Lord Roberts en die Anglo-Boere Oorlog (1899-1902): 'n

Kritiese evaluering van sy opperbevelskap na verloop van 100 jaar". Journal for Contemporary History 27/2. 2002. 60.

${ }^{5}$ Cd 426. Proclamations, August 1900, 14; Hattingh op. cit., p. 32, 38; Spies op. cit., pp. 148-149.

${ }^{6} \mathrm{Cd}$ 426. Proclamations 12 and 14 August, 14, 18; Hattingh op. cit., p. 39.

${ }^{7}$ See Spies, SB \& Nattrass, G. Jan Smuts: Memoirs of the Boer War. Johannesburg: Jonathan Ball, 1964, 96.

${ }^{8}$ South-African National Archives Pretoria (hereafter NASAPta). A313. De la Rey versameling. Part 9. Letters. De la Rey to L Botha, 12 July 1900, 65 f.

${ }^{9}$ Official sources differ as to exact numbers. The author has used those of JH

Breytenbach. Die geskiedenis van die Tweede Vryheidsoorlog in SuidAfrika, 1899-1902. Vol. IV. Pretoria: Government Printer, 1983, 323.

${ }^{10}$ NASAPta. Landdrost of Potchefstroom (ZPO). Vol. 27. Telegrams. LanddrosPres. Kruger, Jan-May 1900.

${ }^{10}$ NASAPta. Milner Papers (MP), 45(a).

${ }^{11}$ Smuts op. cit., p. 96.

${ }^{12}$ NASAPta. A313. De la Rey versameling. Part 8. Dagboek. De La Rey to L Botha, 12 July 1900. Copy in Ferdinand Postma Library, Potchefstroom.

13 Ibid., p. 65 f.

${ }^{14}$ NASAPta. High Commissioner (HC). Vol. 38. Intelligence Summary, 7

September 1900; Vol. 41. Intelligence Summary, 29 July 1900.

${ }^{15}$ NASAPta. Military Governor Pretoria (MGPta). Vol. 27. 3867/1900. MaxwellWard, 25 September 1900.

${ }^{16}$ NASAPta. Lord Roberts Papers (LRP). Vol. 52. Barton to Military Secretary, 1 October 1900, 2.

${ }^{17}$ Ibid.

18 "Memories of Yesteryear". (Memories of JJ Hartley). Potchefstroom Herald, 20 August 1976.

${ }^{19}$ The most authoritative work on what has become known as the first De Wet drive is Pretorius, F. "Die eerste dryfjag op hoofkommandant CR de Wet". SuidAfrikaanse Akademie vir Wetenskap en Kuns. Christiaan de Wet Annale. Part 4. Bloemfontein, 1976.

${ }^{20}$ NASAPta. LRP. Vol. 44. Smith-Dorien-Roberts, 6 August 1900, 2 f.

${ }^{21}$ NASAPta. LRP. Vol. 10. Operations Frederikstad, 31 July - 1 Sept, 1 September 1900, 106-108 f.; Vol. 44. Smith-Dorien-Roberts, 6 August 1900, 2 f. 
${ }^{22}$ NASAPta. Vol. 10. LRP. Smith-Dorien to Roberts 6 August 1900.

${ }^{23}$ See Spies op. cit., p. 45.

${ }^{24}$ Cd 426, Proclamation No. 5 of 1900, 19 June 1900, 10.

${ }^{25}$ NASAPta. A2044. South African Despatches. Vol. 4 No. 6. Roberts to Secretary of War 10 October 1900, 48.

${ }^{26}$ NASAPta. LRP. Vol 44. Smith-Dorien to Roberts. 6 July 1900, 3.

${ }^{27}$ NASAPta. LRP. Barton to Roberts, 17 October 1900, 40.

${ }^{28}$ See Spies op. cit., p. 109.

${ }^{29}$ Cd 425. Proclamations 5 and 6, 10 -11; NASAPta. MGPta 29 May 1900, 25

August 1900. Notice 115 of 1900, 28 September 1900 Cd 426, 19-20; Spies.

op. cit., pp. 108-110; Hattingh op. cit., p. 32.

${ }^{30}$ NASAPta. MGPta. Proclamations 31 April 1900; Hattingh op. cit., p. 41.

${ }^{31}$ Cd 524. Return of buildings burnt in each month, June 1900 to January 1901.

${ }^{32}$ NSAPta. LRP. Telegrams and Letters. Vol. 5, Roberts to Clements, 34, 23

September 1900. Cited in Spies op. cit., p. 122.

${ }^{33}$ Ibid.

${ }^{34}$ Ibid. See also MGPta. 205 C/15/00.

${ }^{35}$ NASAPta. LRP. Vol. 52. Barton to Military Secretary, 1 October 1900, 2.

${ }^{36}$ Montague, WE, “Campaigning in South Africa, 1900-1901: By a Mounted Black”. Edinburgh Press, 1901, 37.

${ }^{37}$ NASAPta. LRP. Vol. 46. Telegram, Hart to Roberts, 3 September 1900, 2;

A2044. SA Dispatches. Vol. 2 No. 6. Roberts to Secretary of War, 10 October 1900, 62.

38 Ibid.

39 Ibid.

${ }^{40}$ These clashes resulted in the death of the Boer hero Danie Theron on 5

September.

${ }^{41}$ NASAPta. LRP. Vol. 46. Telegram Hart to Roberts, 7 September 1900, 14.

42 Ibid.

43 Ibid.

${ }^{44}$ Ibid. pp. 25-28.

45 Ibid.

46 Ibid.

${ }^{47}$ A2044. South African Despatches. Vol. 2. Roberts to Secretary of War, 190.

${ }^{48}$ NASAPta. LRP. Vol. 54. Report of Operations, Hart to Roberts, 2 October 1900, 92-95.

49 Telegram. Hart to Roberts, 19 September 1900, 44-45. 
${ }^{50}$ Telegram Barton to Military Secretary, 1 October 1900, 2.

${ }^{51}$ Barton to Roberts, 3 October 1900, 8.

${ }^{52}$ Ibid., p. 40.

${ }^{53}$ Ibid. p. 46.

${ }^{54}$ Ibid.

${ }^{55}$ Spies op. cit., p. 147; NASAPta. LRP. Vol. 9. Methuen to Roberts, 29 October 1900, 5.

${ }^{56}$ Pienaar, P \& Ebeling, AJJ. Met Steyn en De Wet. Middelburg: Den Boer, 1902, 171-172.

${ }^{57}$ NASAPta. ZPO 294a. District Commissaris. Brieven Copieboek. Edwards to Liebenberg, 13 July 1900.

${ }^{58}$ Ibid; MGPta Annexure A. Circulars. Importation of foodstuffs, 1 December 1900.

${ }^{59}$ Scorgie, R. Memories of yesteryear: My swan song. Potchefstroom Museum, 1971, 108.

${ }^{60}$ NASAPta. LRP. Vol. 46. Hart to Roberts, 13 September 1900, 30; Vol. 54. Hart to Roberts, 17 September 1900.

${ }^{61}$ The Gatsrand is delimitated by the Mooi River in the north-west, the N17 highway from Potchefstroom to Johannesburg and R500 joining Carletonville and Fochville.

${ }^{62}$ NASAPta. A1643. Staff Diaries 1784. Potchefstroom Sub-District, Dec. 1900 January 1901.

${ }^{63}$ Ibid.

${ }^{64}$ Ibid.; NASAPta. LRP. Confidential telegrams. Vol. 215 No. 364. Roberts to Secretary of War, 5 November 1900.

${ }^{65}$ Hattingh op. cit., p. 94; Spies op. cit., pp. 150-152.

${ }^{66}$ NASPta. LMP. Telegrams and letters. Vol. 3. Roberts to Barker, 3 August 1900, 126.; Military Secretary (PSY). 57/DC 248. Edwards to Fides, 1 August 1900; See also Grundlingh, A. The dynamics of treason. Pretoria: Protea Book House, 2006, 84-85.; Otto op. cit., p. 34: Spies op. cit., p. 147.

${ }^{67}$ NASAPt. LRP. Methuen. Report on Operations, 12.

${ }^{68}$ Ibid.; MGPta. DC 448. Maxwell to Fides; see also Grundling op. cit., p. 85.

${ }^{69}$ NASAPt LRP. Vol. 52, Barton to Roberts, 30 October 1900, 91.

${ }^{70}$ Ibid.

${ }^{71}$ Kriel, JD. "Emily Hobhouse en die naweë van die Anglo-Boereoorlog” DPhill dissertation. University of the Free State, 1956, 34. Cited from a press statement by Sykes. For other speculations on the earliest concentration camps to be opened in the Transvaal see Otto op. cit., p. 55; Hattingh op. 
cit., p. 49; Spies op. cit., p. 143, f; Amery, LS. The Times history of the war in South Africa. Vol. III. London: Low, Marston, 1906-7, 118.

72 NASAPta. LRP. Vol. 59. Douglas to Roberts, 11 November 1900.

73 Ibid.

${ }^{74}$ Cd 819. Working of Refugee Camps, 47.

${ }^{75}$ Ibid., p. 75.

${ }^{76}$ Stead, WT. Methods of barbarism. London: Mowbray House, 1901, 38. Citing a letter from the Military Governor of Johannesburg. 